1632

山本機械学会論文集(C 編)

62 娄 $596 \div \frac{1}{5}(19964)$

論文 No.95 1168

\title{
高精度繰返し衝擊試験機の開発とその応用に関する研究*
}

\author{
今 戸 啓 二*1, 宮川 浩 臣*1 \\ 三 浦 篤 義*1, 平野 冨土夫*2
}

\section{Development of Repetition Impact Tester and its Application}

Keiji IMADO, Hiroomi MIYAGAWA,

Atuyoshi MIURA and Fujio HIRANO

\begin{abstract}
In order to investigate elastic or plastic deformation process of metals or other materials, an accurate impact test rig was developed. It consists of a gas bearing and a spindle as a hammer in order to minimize the effect of friction and increase the accuracy of measurement. Unlike the Shore rebound scleroscope, the impact hammer of the rig is free from restriction and allows natural rebounds, which provides more information from experiments such as variation of the coefficient of constitution with increment of impact times. Behavior of the hammer is measured with a laser Doppler vibrometer and a proximity sensor. By means of this rig, the deformation process from an elastic to plastic region within less than $0.5 \mathrm{~ms}$ was studied and a simple linear relationship between displacement and contact force was found. The effect of surface condition or bolted joint condition on rebounding behavior was also studied. From these experiments it was confirmed that this impact tester is useful for the investigation of tribological phenomena.
\end{abstract}

Key Words: Material Testing, Measurement, Surface Roughness, Bolted Joint, Coefficient of Restitution

\section{1. 緒}

現在最も一般的に行われている硬さ試験にはブリネ ル、ビッカース硬さなどの押込み硬さのほかにショア が考案し，Taborにより合理的な説明(1)の)与えられた ショア反発硬さがある。特に反発硬さ試験は試験機が 小形で取扱いが簢便なため，押込み硬さと比較して測 定值にばら一つがあるにもかかわらず上く用いられて いる。そこで、こ0ばらつき少小くすることができ れば，反発硬さ試験の適胿範同はさらに抎大寸るもの と考えられる。

著者らはこれまでにアームゲ式の緥这し衝撃試験機 を用いて，衝撃荷重下に扔ける油膜の举動(2)やずムの) 粘弹性特性の解明を行い(3), 油膜の強度や, コムのば 权定数，粘性減衰係数などの推筀に，文発形の衝撃試 験が有効であることを示した。これらの実験で使用し た試験機はアームの先端をH：子としたため，1湔子の運 動にアームの湖有振動が重量される久点があのたが, アームの剛性が比較的強いため，括現性りある拣験が できた。しかしながらアーム系り拔動によるエネルギ

* 㸟稿受付 1995 作 8 月 13 日 13

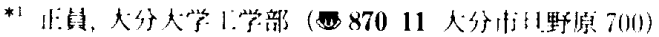

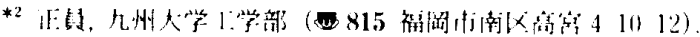

一揁失がやや大きいため，皮膜の影響などのように， より高い感度を要する試験に対しては問題があった。 そこで固有拢動の影製はハンマをスピンドルにするこ とで小さくし，さらにそのガイドに空気軸受を利朋し て摩摖の影帮をほとんど受けない高精度な衝撃試験機 を開発することができた。本研究はそれを胵いて材質 や，粗さや皮膜など表面状態の基なる金属の，衝撃荷 重下における変形過程や反発举動を調べた。その結果， 塑性変形を伴う衝撃㫦重トにに打ける変位と接触力口関

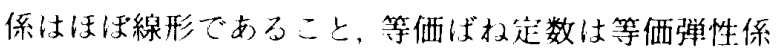
数にほぼ比例することなど，いくつかの何肺な知兒を 得ることができた。

また反発举動が陚験片の取付け状態に非常に鋭敏で あることに着目して、これまで超音波(4)や磁気セン サ(5)などを利用した高価なっ法でしかその評価の困 難なねじ継一手部の診断にも惢用し，繰返し衝撃試験機 がこのようなトライボ現呂の評価にも有効であること を过す。

\section{2. 実 験 方 法}

网1に衝撃試験機の概略を亦寸。衝撃試験機は大小 2 種類あり，以ト0四中では小さいほうがType I, 大 きいほうをType II として表している。そ扎゙゙れの箱 
気軸受の内径 $\times$ 長さが $\phi 15 \times 50, \phi 25 \times 80 \mathrm{~mm}$ である 以外は，ほとんど類似しているので, 罒 1 では小形の 装置のみを示している. 衝撃はスピンドルの先端に压 子として軸受鋼球 (SUJ 2)，超硬合金球(WC)，あるい は空化けい素球 $\left(\mathrm{Si}_{3} \mathrm{~N}_{4}\right)$ を玨入したスピンドルを，所 定の高さより落下させて与えた。落下高さは静かに置 いた状態を零として，近接センサからの出力電压をも とに，所定の高さになるよう調整ねじで合せた，表 1 に衝擊試験機の主要諸元を示す。図10㹡大汹に示す ように，上部が開放する構造の鋼線のトリガに細い系 を通し，系を強くにに引き上げることでハンマは解放 される.八ンマの速度はレーザドップラー振動計によ り計測し, $1 \mathrm{~ms}$ 以内のハンマの変位は振動計の速度 出力を積竹して求め，それ以上の期間では変位センサ を利用した。接触力は速度を微分した加速度より求め た。

表面状態の影響を調べるため, 試験片はS $45 \mathrm{C}$, SS 400, SUS 304, SUS 403, アルミニウム (以下Al と略す)，およびアルミニウム合金 A 20240６種類を 準備し，表面に黒皮がある压延のまま（as rolled）のも

Table 1 Main items of impact tester

\begin{tabular}{|c|c|c|c|c|c|}
\hline Type & Ball & $\begin{array}{c}\text { Ball dia. } \\
, \mathrm{mm}\end{array}$ & $\begin{array}{c}\text { Weight } \\
, \mathrm{N}\end{array}$ & $\begin{array}{c}\text { Dia of } \\
\text { spindle }\end{array}$ & $\begin{array}{c}\text { Air pressure } \\
, \mathrm{KPa}\end{array}$ \\
\hline Type I & $\mathrm{SUJ}_{2}$ & $\phi 11.11$ & 0.784 & $\phi 15$ & 49 \\
$\mathrm{Si}_{3} \mathrm{~N}_{4}$ & $\phi 11.11$ & 0.735 & $\phi 15$ & \\
\hline Type II & $\mathrm{WC}$ & $\phi 10.0$ & 3.31 & $\phi 25$ & 98 \\
\hline
\end{tabular}
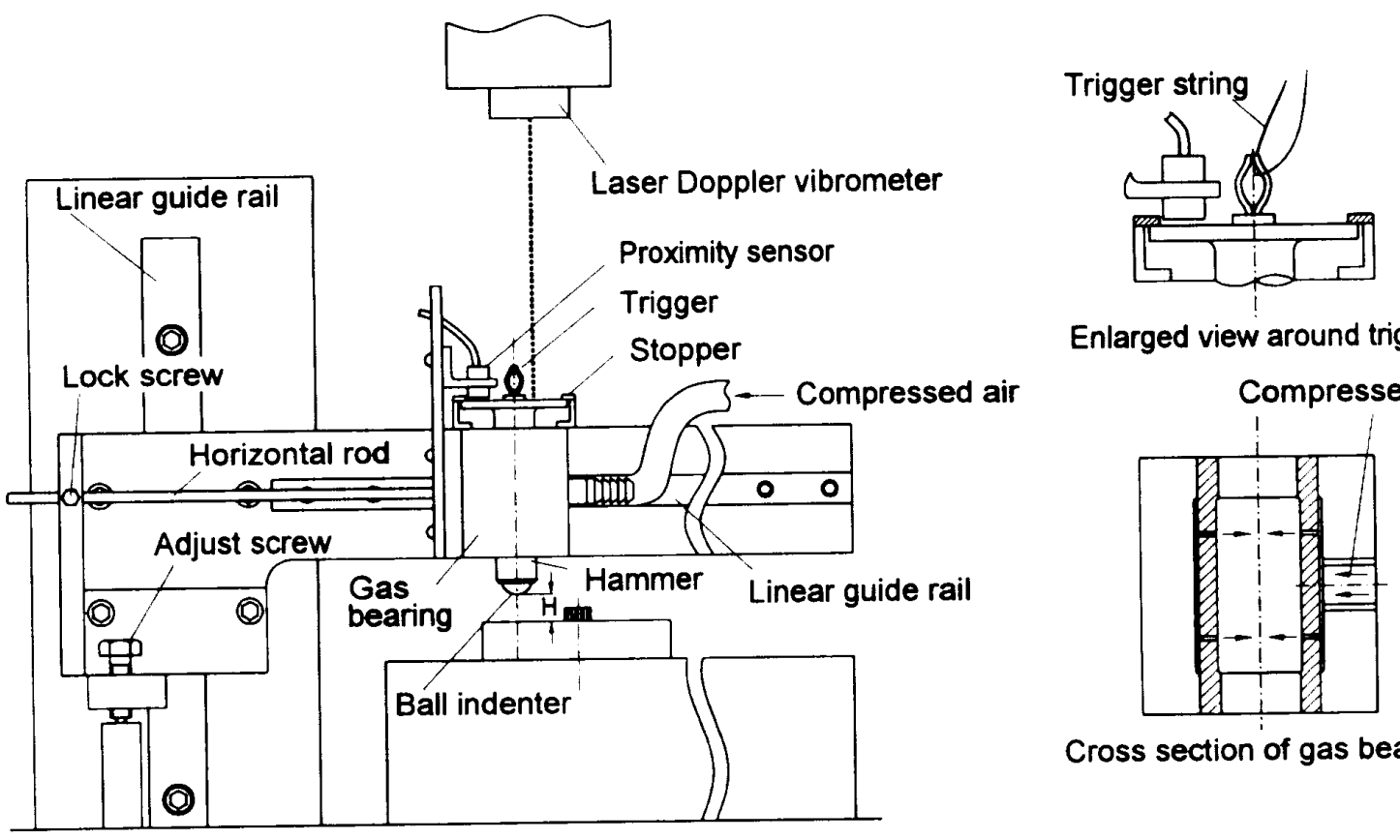

Enlarged view around trigger

Compressed air

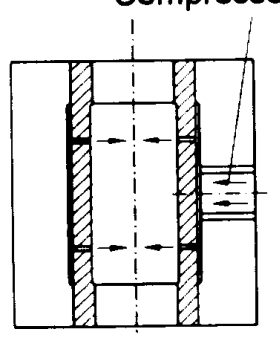

Cross section of gas bearing

Fig. 1 Experimental apparatus 
る変位と接触力の関係を調べた実験では，バフ仕上げ して 粗さ $0.04 \sim 0.1 \mu \mathrm{m} \mathrm{Ra}$ の Al, S $45 \mathrm{C}$, 黄銅, SUS 304, SUJ 2 および超硬(WC)の) 6 種類の試験片 を用いた。それらの試験片の形状扔よび弾性係数を表 3 に示す。衝撃はWCに対して $\phi 48 \mathrm{~mm}$ の山周上に加えた。

ねじ締結部への適用については，長さ $230 \mathrm{~mm}$, 板

Table 3 Properties of the test specimen

\begin{tabular}{|c|c|c|c|c|c|c|}
\hline & $\begin{array}{c}\text { Size } \\
\mathrm{mm}\end{array}$ & $\begin{array}{c}\mathrm{E}_{1} \\
\mathrm{GPa}\end{array}$ & $\begin{array}{c}\mathrm{E}^{*} \\
\mathrm{GPa}\end{array}$ & $\begin{array}{c}\mathrm{K} \\
10^{7} \mathrm{~N} / \mathrm{m}\end{array}$ & $\begin{array}{c}\mathrm{K} / \mathrm{E}^{*} \\
10^{-4} \mathrm{~m}\end{array}$ & $\zeta *$ \\
\hline Aluminum & $\phi 68 \times 10$ & 70.3 & 126 & 1.16 & 0.92 & 0.61 \\
\hline S45C & $\phi 68 \times 10$ & 206 & 273 & 2.65 & 0.97 & 0.29 \\
\hline Brass & $\phi 68 \times 10$ & 103 & 170 & 1.49 & 0.88 & 0.45 \\
\hline SUS304 & $\phi 60 \times 10$ & 193 & 263 & 2.37 & 0.90 & 0.48 \\
\hline SUJ2 & $\phi 60 \times 6$ & 208 & 275 & 3.26 & 12 & 0.08 \\
\hline WC & $\phi 32 \times 4$ & 620 & 458 & 4.03 & 0.88 & 0.05 \\
\hline
\end{tabular}

* $2 / \mathrm{E}^{*}=\left(1-v_{1}{ }^{2}\right) / \mathrm{E}_{1}+\left(1-v_{2}^{2}\right) / \mathrm{E}_{2}, \mathrm{E}_{1}, v_{1}$ : Test piece $\mathrm{E}_{2}, v_{2}:$ Indenter $\left(\mathrm{Si}_{3} \mathrm{~N}_{4}\right)\left(\mathrm{E}_{2}=320 \mathrm{GPa}, v_{2}=0.27\right)$

** Loss factor

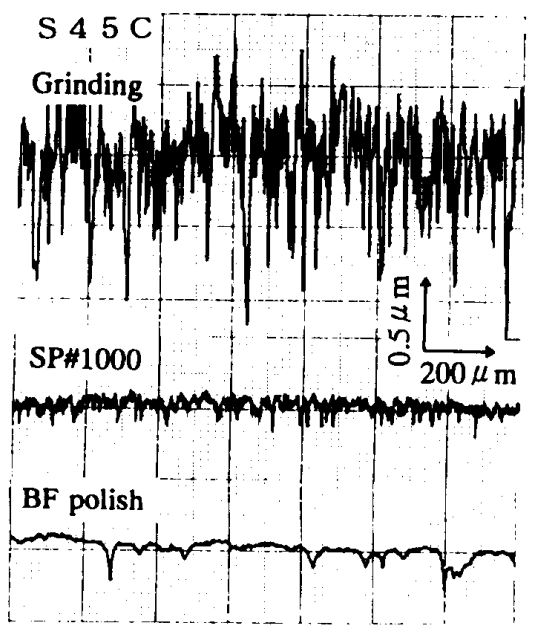

Fig. 2 Surface roughness

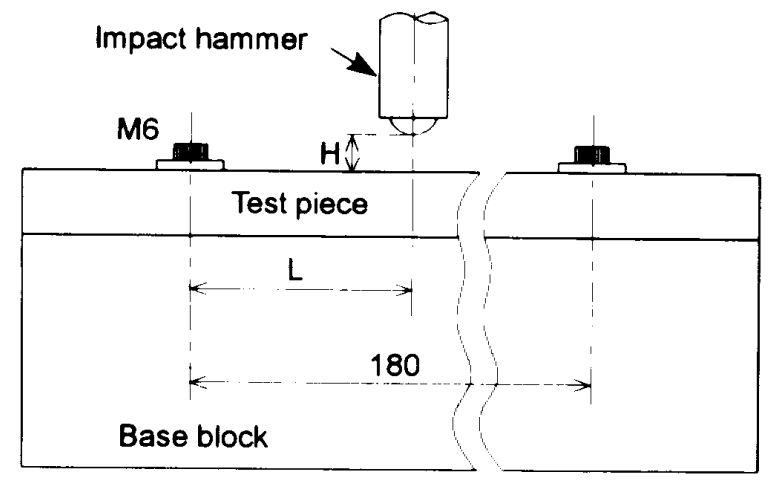

Fig. 3 Impact location on plate
厚 $8.5 \mathrm{~mm}$, 幅 $100 \mathrm{~mm}$ の試験片を用い，図 3 に示す ようにその一端(以下片締めとよぶ)，あるいは 180 $\mathrm{mm}$ の間隔でその両端(以下両締めとよぶ) を重量 300 Nのベースブロックに机じで固定した。試験片は外周 をフライス加工した SS 400 平鋼を研削して $1.5 \mathrm{~S}$ $(0.432 \mu \mathrm{m} R a)$ に仕上げた。締結ねじはJIS 1176 六角 穴付ボルトM 6(強度区分 12.9)で，締結部のねじ部の 長さは $11 \mathrm{~mm}$ とし, JIS B 1256 のみがき丸平座金 1 種(厚さ $1 \mathrm{~mm}$ になるように加工したもの)を介して

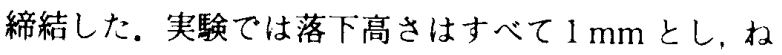
じ中心部から打撃点までの距隻 $L$ を変化させて反発 挙動の変化を調べた。好じには締付けトルクと締結力 の間のばらつきを小さくするように、二硫化モリブデ ンを混入した油を埿布し、トルク $4.8 \mathrm{Nm}$ で締結し た.

\section{3. 実験結果および考察}

\section{$3 \cdot 1$ 金的の材诈および表面状態に対する衙撃試験}

$3 \cdot 1 \cdot 1$ 表面状態の繰返し反発挙動への影響図 4 はレーザドップラー振動計による速度計測の例で, SS 400 の黒皮付きと，研削したものでは繰返し反発 中の速度の堿衰状態に違いが認められ，表面が硬い黒 皮のほうが減衰しにくいことがわかる。このように自 由な絽返し反発挙動をさせたほうが、ショア硬さのよ うに1回のみの反発で停止させるより, 両者の違いが より明りょうになる。また反発係数 $\varepsilon$ は図に示してあ るように，各衝擊点での衝突速度と反発速度の比とし てレーザドップラー振動計の記録より簡単に求まる。

$3 \cdot 1 \cdot 2$ 接触時間中10加速度の変化図 5 は落下 高さ $H=0.5 \mathrm{~mm}$ で成子が窒化けい素球の場合の Al, S 45 C およびSUJ 2 についての, 接触時間中の加速 度の変化を示寺．衝突前の平行部がわずかに泥である のは重力加速度によるものである，図より最大加速度 は硬さの大きい材質ほど大きくなり，硬さの低い $\mathrm{Al}$ では加速度曲線は非対称であるが，S45CとSUJ 2

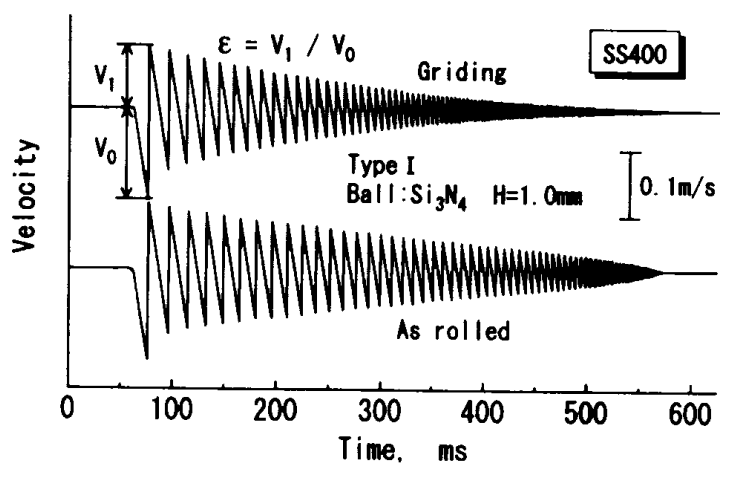

Fig. 4 Change of velocity with time 


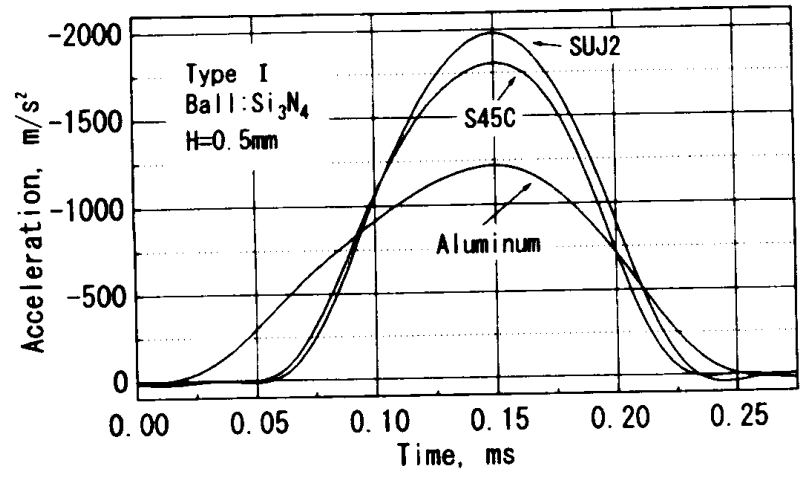

Fig. 5 Change of acceleration with time

ではほとんど正弦波に近い形状(6)となっている。最も 弾性的な衝突と·考えられるSUJ 2 について，窒化けい 素球と軸受鋼の間の等価弹性係数 $E^{*}=275 \mathrm{GPa}$ と表 1 に与えられている值を用いて理論計算 ${ }^{(7)}$ を行うと， 理論加速度は $2280 \mathrm{~m} / \mathrm{s}^{2}$ となり実験值より $15 \%$ 程度 大きく、理論接触時間は $0.16 \mathrm{~ms}$ で, 実験値の 0.17 $\mathrm{ms}$ よりやや短い值となる。理論計算は摩擦や振動に よるエネルギー損失はまったく考慮していないが，現 実にはエネルギ一損失が生じるため，実際の衝突では 加速度すなわち接触力は理論值より $15 \%$ 程度小さく なるものと思われる。

$3 \cdot 1 \cdot 3$ 変位と接触力の関係図 $6 \sim 8$ に初回の衝 笑時間中の落下球の食込み変位 $h($ 接触点を零として 食込み方向を正とする) と接触力 $P$ との関係を示す. 変位 $h$ は近接センサでは時間遅れがあるため, 図 4 の ような速度曲線を積分して求め，接触力 $P$ は加速度 にハンマ質量 $m$ をかけて求めた。すなわち重力加速度 を $g$ とすると

$$
P=m(g-\ddot{h})
$$

である。これより食込み初期(ヘルツの接触理論(7)で はPœh $\left.h^{1.5}\right)$ を除き, 接触力 $P$ は変位 $h$ に比例してお り，両者の関係は線形近似できることがわかる. $0.2 \sim 0.4 \mathrm{~ms}$ 程度の極めて短時間内に起こる数 $\mu \mathrm{m}$ 程 度の微小な食込みに対し，塑性変形を伴う高速変形で は図 6 に示しているようにヘルッの理論式からの偏差 が認められ，hの大きな範囲では近似的に線形である ことがわかる。

$3 \cdot 1 \cdot 4$ 等価ばね定数に対する考察次にエネル ギー損失率，すな⿰七入力エネルギーに対する損失工 ネルギーの割合を考えてみる。入力エネルギーEは八 ンマ重量を $W$ ，落下高さを $H$ とすると $W H て ゙ あ り ，$ これは食込み過程に消費されるエネルギーと等しいの て

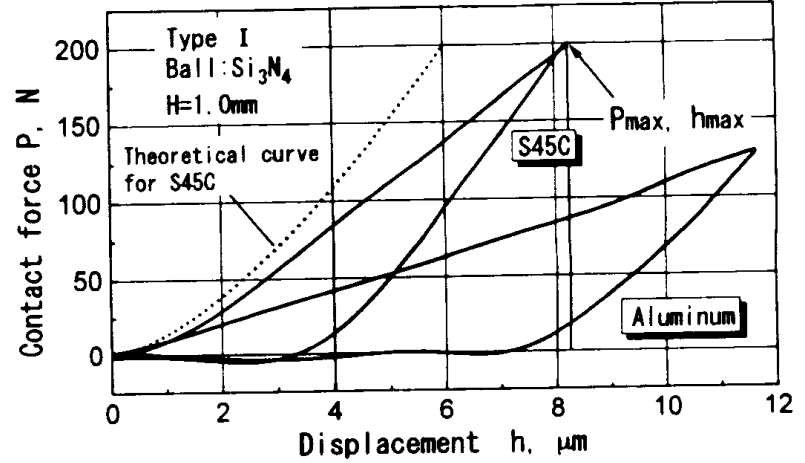

Fig. 6 Relation between displacement and contact force

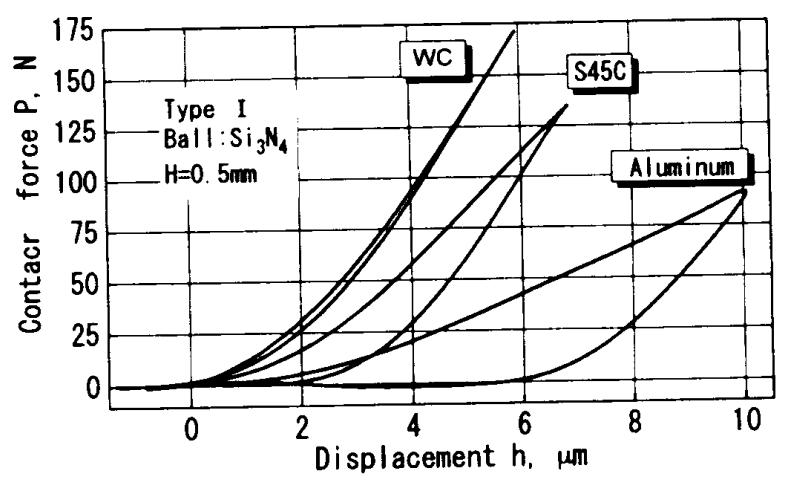

Fig. 7 Relation between displacement and contact force

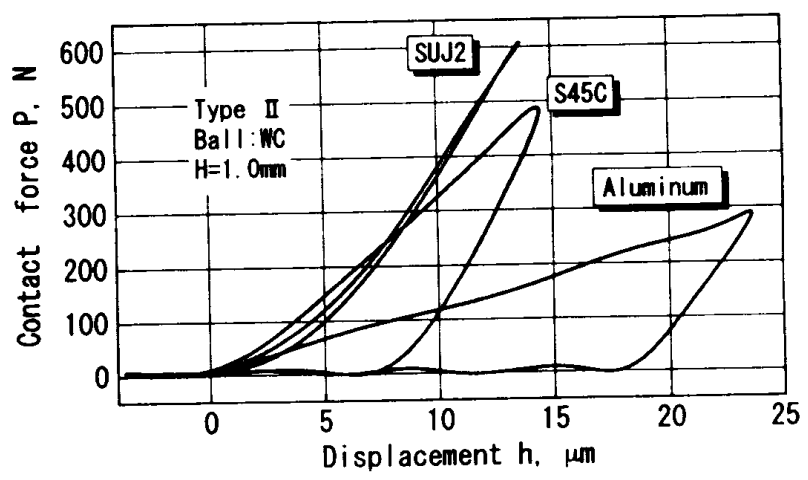

Fig. 8 Relation between displacement and contact force

$$
E=W H=\int_{0}^{h_{\max }} P d h
$$

となる，最後の項は食込み過程中の $P-h$ 曲線と $x$ 軸 で囲まれた面積となる，接触時間中の損失エネルギー はP-h線図、上に描かれるヒステリシスループ内の面 積となる。明らかに Al の場合に最大で、SUJ 2 や WC では非常に小さいことがわかる。これらのヒステリシ スループより，入力エネルギーに対寸る損失エネルギ 一の比であるエネルギー損失率らは次の式で求めら 
れる。

$$
\zeta=\frac{\oint(h d P-P d h)}{2 \int_{0}^{h_{\max }} P d h}
$$

各材質の $P-h$ 曲線から求めたエネルギ一損失率 $\zeta の$ 值は表 3 に示している。衝突速度を $V_{0}$ とすれば，衝揧 で失うエネルギーは

$$
\frac{1}{2} m V_{0}^{2}\left(1-\varepsilon^{2}\right)=\zeta \int_{0}^{h_{\max }} P d h
$$

となり，エネルギー損失率を速度記録より求まる仅発 係数で表すと $1-\varepsilon^{2}$ となる。その值と式(3)から求め たらとは図9に示すように良好に一一致し, 本試験機と 測定值のいずれの精度も十分なことがわかる。

さて，変位 $h$ と接触力 $P$ の関係を線形近似すれば， 近似モデルでのエネルギー $E_{L}$ は $E_{L}=P_{\max }^{\prime} h_{\max }^{\prime} / 2$ と なる.ここで $P_{\max }^{\prime}, h_{\max }^{\prime}$ は近似モデルでの最大接触力 と最大変位である. 奏際の最大変位 $h_{\max }$ は接触点が不 明りょうなため評価することが難しい。，一方，最大接 触力 $P_{\max }$ は容易に求められるので， $P_{\max }^{\prime}=P_{\max }$ とし て $E_{L}$ と式(2)のWHを等置すれば，等価ばね定数 $K=P_{\max }^{\prime} / h_{\max }^{\prime} は$,

$$
K=\frac{P_{\max }^{2}}{2 W H}
$$

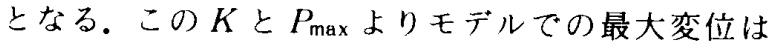
$h_{\max }^{\prime}=P_{\max } / K$ として求まる， $h_{\max }^{\prime}$ は弾性変形が主体 で曲線部が長いと， $h_{\max }^{\prime}<h_{\max }$ となるが，塑性変形の 影響が大きくなると， $h_{\max }^{\prime} \fallingdotseq h_{\max }$ となる。式(5)で求 めた $K$ の值を表 3 に示す.その值と压子と試験片の弾 性係数から求めた等価弾性係数 $E^{*}$ の比は， $K / E^{*}=$ $\left(0.88 \sim 1.2 \times 10^{-4} \mathrm{~m}\right)$ となり，塑性変形を伴う微小変形 ではほほ一定であることがわかる。

$3 \cdot 1 \cdot 5$ 落下高さと接触力の関係 図 10 はバフ仕 上げしたS45CとAIについて，落下高さを変化させ た場命の最大接触力の変化を示す。これより最大接触

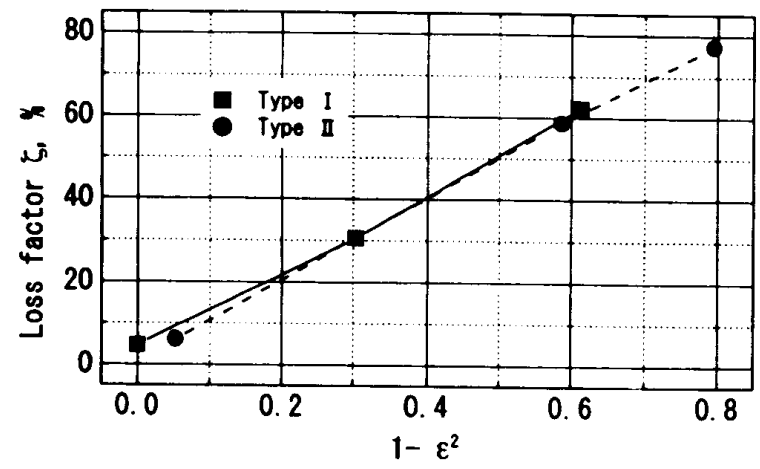

Fig. 9 Relation between $1-\varepsilon^{2}$ and $\zeta$
力はほほ落卜高さの平厅根，才なおち衝笑速度に比例 して增加することがわかる。それぞれの衝突速度は $V_{0}$ $=0.14 \mathrm{~m} / \mathrm{s}(H=1 \mathrm{~mm}), 0.099 \mathrm{~m} / \mathrm{s}(H=0.5 \mathrm{~mm})$, $0.063 \mathrm{~m} / \mathrm{s}(H=0.2 \mathrm{~mm})$ である。衝乫時の力積を考え ると, 落下高さの平方根に比例して增加する衝突速度 が接触時間中の平均接触力を增加させるが，等価ばね 定数 $K$ が塑性変形中はほぼ線形であるため, 最大接 触力も衝突速度に比例して増加することになる。

3・1・6 反発係数と表面状態の関係図 11 に仕上 げ法，材質を異にした場合の反発係数と最大接触力の 関係を示寸，反発係数は弾性係数が大きい材質ほど大 きく，同じ弾性係数をもつ材質では，表面粗さが大き いほど反発係数は小さくなる。これは真実接触面積が 粗さの大きい面ほど小さく，接触点では接触心力が非 常に大きくなり，塑性変形に消費されるエネルギーが 增加するためである，表面皮膜の影響については，黑 皮のあるSS 400 のほが表面が硬いため, 研削仕上 げしたものと比較して反発係数は大きくなっている。 またアルマイト処理をほどこした Alについても同様 である。

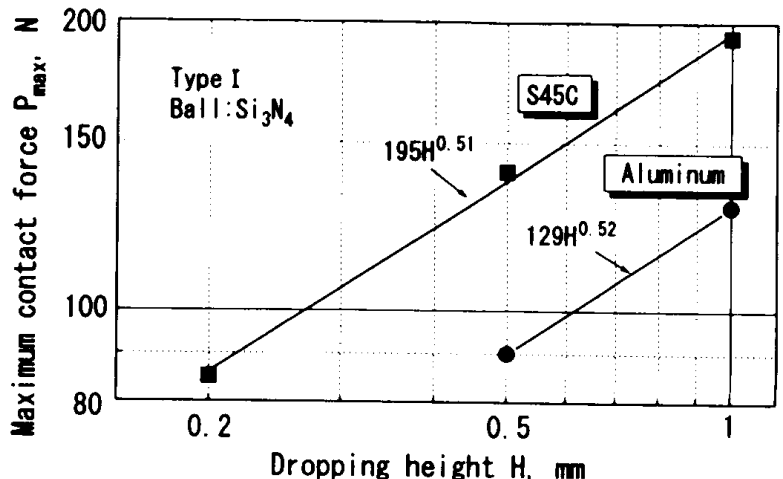

Fig. 10 Relation between dropping height and maxi. mum contact force

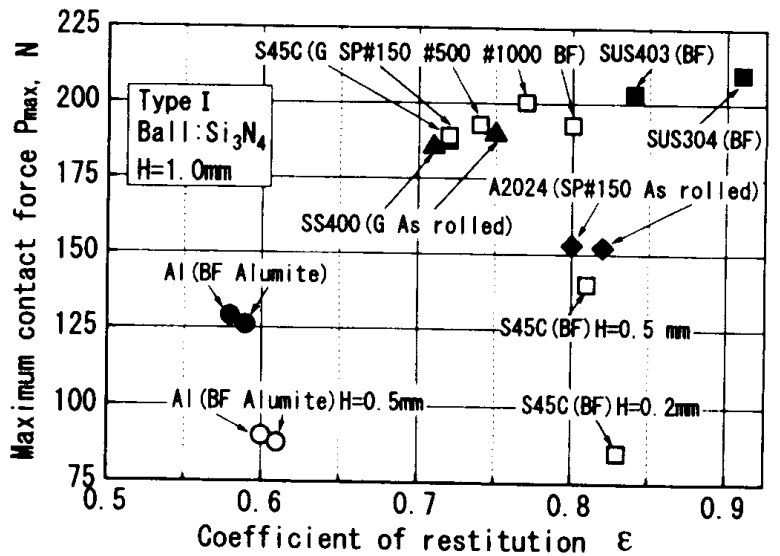

Fig. 11 Relation between coefficient of restitution and maximum contact force 
$3 \cdot 1 \cdot 7$ 深下高さと玨こん径抢よび反発係数の関係 実験後に生じた压こんの直徍 $d$ は, BF の S $45 \mathrm{C} て ゙$ はそれぞれ $d=0.5 \mathrm{~mm}(H=1 \mathrm{~mm}), 0.43 \mathrm{~mm}(H=0.5$ $\mathrm{mm}), 0.35 \mathrm{~mm}(H=0.2 \mathrm{~mm})$ となり、この3 点につい ての $P_{\max }$ と $d$ を用いて計算したマイヤ一指数 ${ }^{(1)}$ は 2.25 となる.この值は静的押し込み硬さにおけるマイ ヤ一指数と同じであり，最大接触力，あるいは衝突速 度と压こん径との指数関係が認めら机る。バフ仕上げ したAlについては $d=0.74 \mathrm{~mm}(H=1 \mathrm{~mm}), 0.63$ $\mathrm{mm}(H=0.5 \mathrm{~mm})$ となり同じくマイヤー指数は 2.15 となる。

料さの最毛小さい仕:げ法である BFについて, 落 卜高さによる反発係数の変化に注意して図 11 を観察 すると， S45C，Al およびアルマイト処理した $\mathrm{Al} の$ いずれも，落下高さの減少に伴い反発係数の增打する ことがわかる。これは落下高さの減少に伴い接触田力 が低ドすれば，塑性降伏を生じる割合が減少して，全 エネルギーに対する叮復叮能な弾性エネルギーの割合 が増加するためと考えられる。

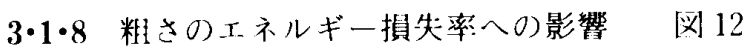

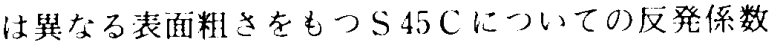

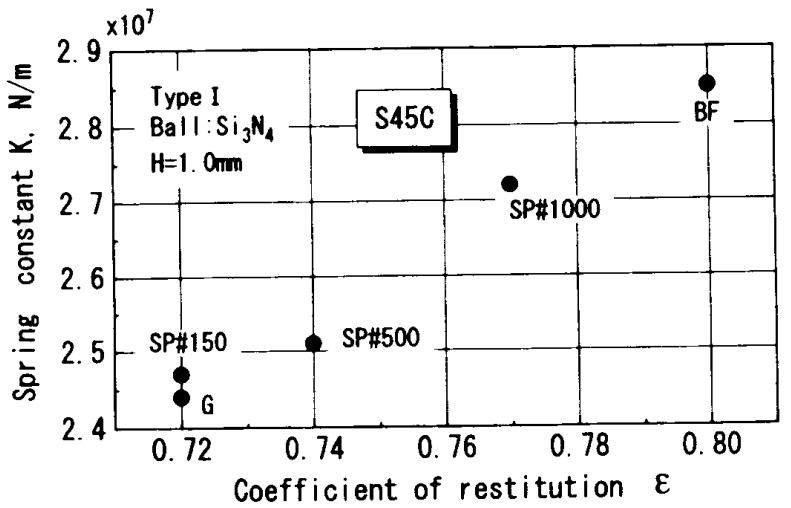

Fig. 12 Relation between coefficient of restitution and equivalent spring constant

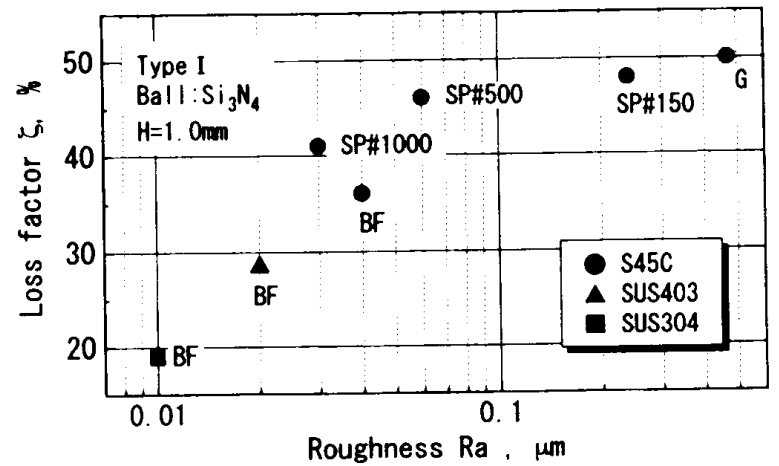

Fig. 13 Relation between roughness and loss factor $\zeta$ $\varepsilon$ と等価ばね定数 $K$ の関係を示す。网より仕上げ法の 影響が明確に認められ，等価ば权定数は材質だけでな く表面粗さにも影響されることがわかる。庈発係数と 等価ば权定数は線形関係が成立し，表面仕上げがよく なるほど, 粗さの平滑化に消費される塑性変形エネル ギーが減少して、反発係数および等洒ばね定数は增加 する。そのことをさらに明確に表すため，図 13 に中心 線平均粗さ $R a$ とエネルギー損失率 $\zeta 0$ 関係を示す. 粗さが大きくなればエネルギー損失率は增加して, 粗 さの平滑化に消費されるエネルギーの増大寸ることが わかる。

$3 \cdot 2$ ねじ締結部に対する街動試験図 14 および 15 はそれぞれ闭締め，片締めに対する反発举動の記録 である。繰返し反発は戍 3 に示したねじ締結部から打 撃点までの距離 $L$ の増大とともに隇衷し，特に片締 め0場合に影著である.刘応する10回までの反発係数 の変化をそ机ぞれ瓦16，17に示寸．いずれ毛初问の反 発係数が最も低く，2[回めに大きく增加し，最初の衝 撃での塑性変形によるエネルギー損失が認められる。 犮発係数の増加率は $L$ が小さくなるほど大きくなる。 繰返し衝撃に伴う反発係数の変化は，Lが小さい場 合，2[回め以降の反発係数ではわずかな増加しか認め られないが，Lが大きい場合は反発回数の増加ととも

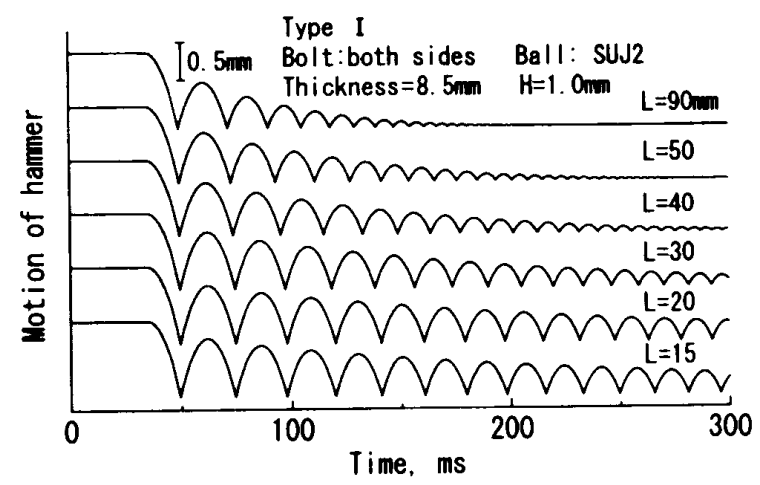

Fig. 14 Rebound of hammer

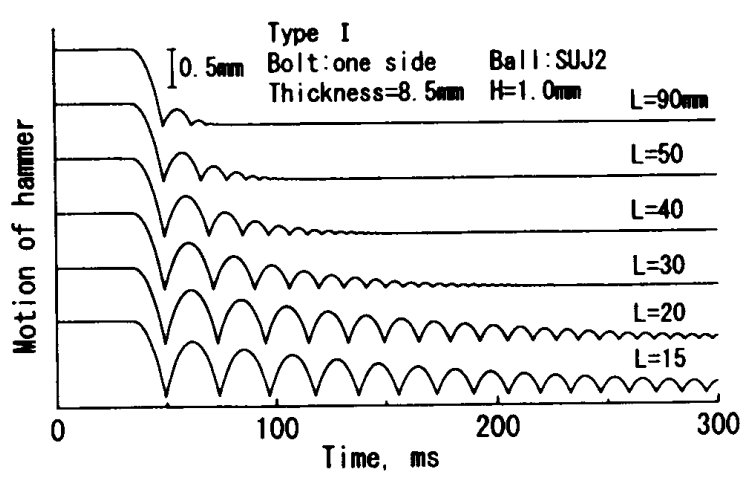

Fig. 15 Robound of hammer 


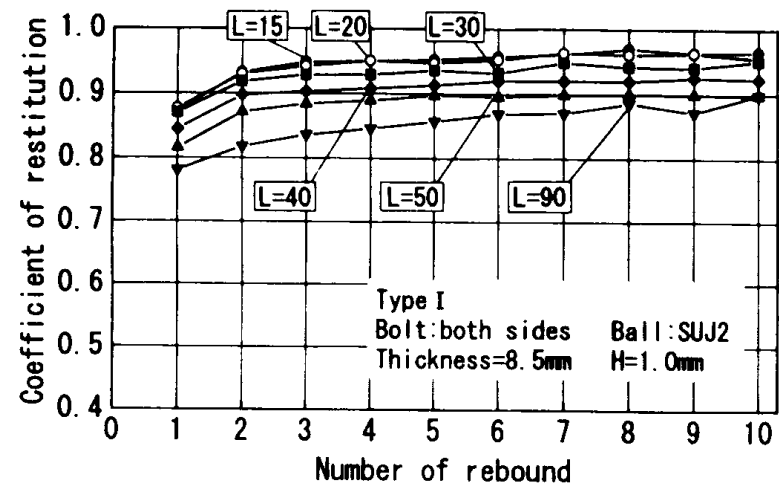

Fig. 16 Coefficient of restitution on plate screwed at both sides

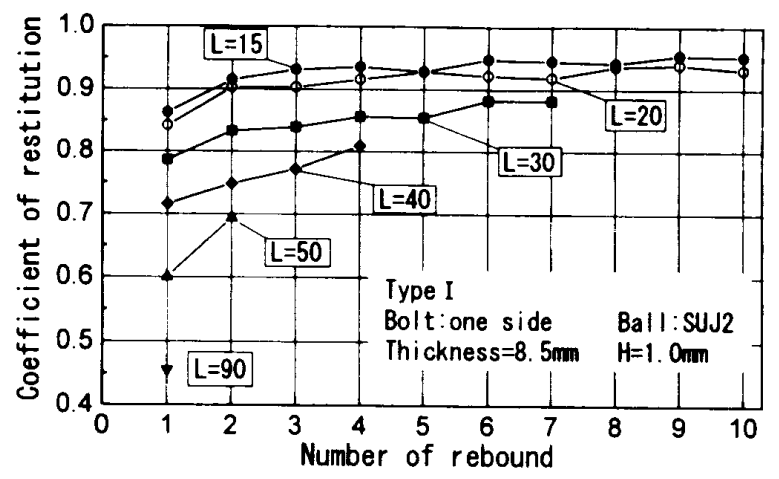

Fig. 17 Coefficient of restitution on plate screwed at one side

に反発係数は増加し片締めの場合に顕著である。こ0) ことは Lが大きくなれば締結王力がほとんどなく(8), 試験片も曲げ振動を生じやすくなり，衝撃による塑性

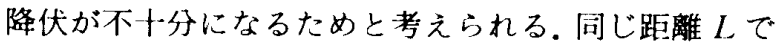
両者の反発係数を比較すると，明らかに両締めのほう が片締めより高いが，Lが小さければ両者の差は非常 に小さい.しかしながら，その後の綝返し反発挙動に おいて幽者の違いが明らかとなり，両締めのほうが減 衰が小さく，長く繰返し反発を䘕うことになる，㠹締 めでは $L$ が小さい場合の締結状態の違いを反発係数 で区別することは困難であるので，図14からそれぞ 九の包絡線を求めると図 18 となり，Lの増加に伴う 振幅減裹のようすがわかりやすい。このように精度の 高い評価を行うには，反発係数より変位で比較するほ うが有利となる。またショア硬さのような単発による 評価では最初の反発高さでその違いを見出すことは難 しく，本研究のように繰返し发発により，おずかな違 いを積分させたほうが区別が容易になる。

このように的じ締結された部材に対して繰返し衝撃 試験を行うことで、締結部からの距離や締結法の違い による反発挙動の相違が簡単に評価できることを示し

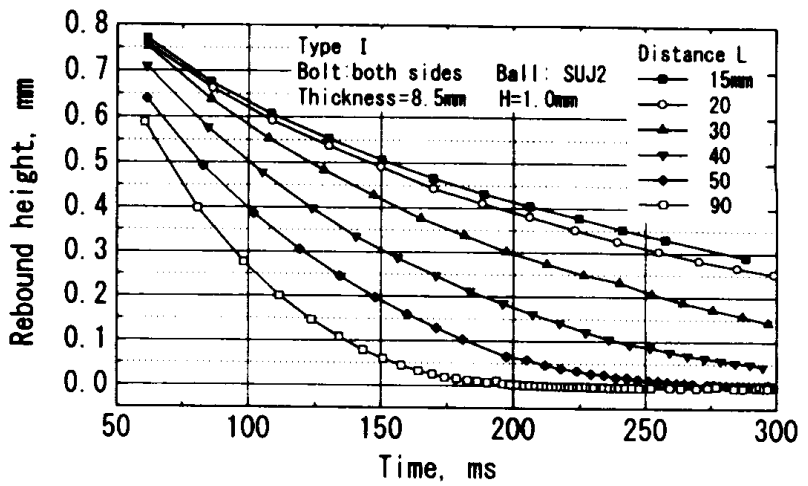

Fig. 18 Envelope curves of rebounds

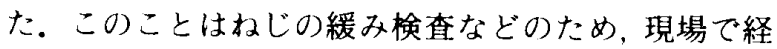
験的に行われているハンマによる打診法に定量性を与 えることのできる可能性を示している．現在机じ䫓部 への直接衝撃で締結力の推定や，フレッチング損傷な どに対する非破壊検査などへも応用し，叮能性のある デー夕が得られており，それらについてはいずれまと めて報告したい。

\section{4. 結 論}

高精度繰返し衝撃試験機を用いて表面状態や材質の) 異なる金属に対する実験と，評価の難しいねじ締結部 に対して行った実験で，得られた結果をまとめると次 のようになる。

（1）粗さが大きいと平滑化に伴う塑性変形でエネ ルギー揁失率は増加し，反発係数は低下すする。

（2）硬い表面皮膜があれば反発係数は上年する。

（3）塑性変形を伴った場合，食込み変位と接触力 の関係はほぼ線形であり，比例定数である等価ばね定 数は等価弹性係数にほほ比例するが、粗さの影響も受 け，粗さが大きくなれい゙等価ばする定数は低下゙する。

（4）最大接触力山衝突速度に比例して增加し、成: こん径と最大接触力を佣いて計算したマイヤ一指数 は，押込み硬さと间程度の約 2 となる。

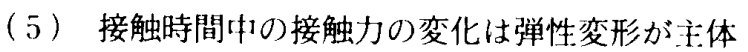
であれば，正弦波に似た形となり，SUJ 2 と窒化けい 素球の間ではヘルツの接触理論による最大接触力と比 較して実測值は $15 \%$ 程度小さな值となった。塑性変形 が支配的な材質では食込み過程と仅発過程は非刘称と なる。

（6）㪀発係数 $\varepsilon$ にるエネルギ一損失率 $1-\varepsilon^{2}$ と、ヒスデリシスループからのエネルギ一損失率らは 一一致して試験機と测定值の精度がーけ行なことが確認で きた。

（7）取発係数は閁締めのほうが片締めより高く， 
极じ締結部から打撃点までの距離の増加に伴い繰返し 反発举動の減衰が大きくなる。

（8）塑性変形を伴う衝撃での反発係数は初回が最 も低く，2回めに大きく増加する。

終わりに実験に協力された大分大学大学院生矢野智 康君に感謝の意を表す。

\section{文献}

(1) Tabor, D., Hardness of Metals, (1951), 115-129, Oxford Clarendon Press, London.

(2) Imado, K., Miyagawa, H., Miura, A.. Ueyama, N. and Hirano, F. Behaviour of Traction Oils under Impact Loads, Trans. STLE, 37-2(1994), 378 386.
(3) Hirano, F., Miyagawa, H., Imado, K. and Kawahara. Y. Impact Tests of Rubber Materials for Seals, Proc. Int. Conf. Fluid Sealing. BHR. (1994), 161192

（4）牧野孝之・酒相智次・鳥山睛彦、超音波を利判したボルト 軸力測定装置の開発上実用化, 精密機械, 43 2(1977)，223232 .

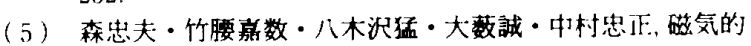
方法によるポルト軸力の測定，機論，47-413，A(1980)， $102-109$.

(6) Engel, P. A., Impact Wear of Materials, (1976), 4748, Elsevier.

(7) Timoshenko, S. P. and Goodier, J. N., Theory of Elas. ticity, (1970), 413 422. McGrow Hill Kogakusha.

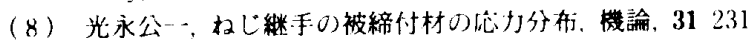
(1965), 1750 1757 . 